\title{
THE ANALYSIS OF ENGLISH SLANGS FOUND IN THE ANTMAN MOVIE
}

\author{
Andri Donal, Andi Rizky Fauzi, Himry Saleh \\ andriando1101@gmail.com,andi_gundoel@yahoo.com, \\ Himrysaleh@gmail.com, \\ English Study Program, Faculty of Teachers Training and Education, \\ University of Pasir Pengaraian
}

\begin{abstract}
This article discusses the meaning and types of English slangs found in the Ant Man Movie directed by Peyton Reed, produced by Wald Disney Studios Motion Pictures, 2015. The main object of the research was to find out the meaning of English slangs found in the Ant Man Movie and classify them depending on its characteristics of English Slangs types. This research used a qualitative method. In Classifying the English Slangs, researchers used theory from Coleman that classifying English slangs into seven; English Slang changes in meaning, English Slang changes in function, English Slang change in form, English Slang created by abbreviation, English Slang changes in spelling, Slangs loans and Slangs from imitating sound. Through this research, researchers found forty English Slangs in the Ant Man Movie; fourteen English Slangs created by changes in meaning, two English Slangs created by changes in, twelve English Slangs created by changes, five English Slangs created by abbreviation, seven English Slangs created by changes in spelling, four English Slangs loans, and two English Slangs are from sound. English slangs are non-register language. It is more acceptable in daily life because it is fresher and simple in use.
\end{abstract}

Keywords: Analysis, English Slang, Ant Man movie, Qualitative method

\section{INTRODUCTION}

English Slang is a kind of language varieties in society. According to Coleman (2012:3), people use the English Slang to impress one another or any girl who might happen to be passing them and to exclude passers-by from their conversation. To identify English Slang, people need to know about who is speaking, whom they were speaking to, where they were, what they were doing, when they were speaking and what they mean. 
English Slangs has a different meaning from Standard English because sometimes they are borrowed from another language and are formed by abbreviation. To comprehend them, people should know the meaning of English Slang.

In the dialogue of movie, actors, and actress often use English Slangs. It is to make the dialog more natural. Based on the explanation above, the researchers were interested to research the analysis of English Slangs in the Ant Man Movie"

The purposes of this research were to find out the meaning and type of English Slangs found in the Ant man movie.

\section{REVIEW OF RELATED LITERATURE}

\section{Definition of English Slangs}

Coleman (2012) said that Slang is not register: Slang is a label for individual uses of individual terms which are inserted into appropriate slots in standard or colloquial English sentence. This means that it is often possible to guess the meaning of unfamiliar Slang Word from its context. Green (2015:14) also said that a slang word as an alternative to more formal word, typically used by a subset of the speech population and colloquial term as an informal term used widely in the speech community. Slang is a language which very familiar is style, and usually restricted to the members of a particular social group, for example, teenage slang and army slang. Slang is not usually understood by people outside a particular social group and so has value in showing the intimacy of its members. It means that English Slang is an informal speech. It is an individual term which is used as an alternative to communicating in a subset of speech population such as Military Slang; webfoot (infantryman), gravel-crusher or cruncher (an infantryman), leatherneck (a soldier or a marine), flyboy (an airman), brown job (an army), coffee cooler (a shirker: a soldier with an easy or safe assignment), dogrobber (an officer's orderly) and boy scout (an inexperienced soldier), Prisoner Slang; jacket (a reputation for treacherous behavior), nonce (sex offender: a pedophile), muppet (a prisoner easily victimized by other inmate) and American college Slang; flunk out (to fail an examination; to be dismissed from college for failing examination), bone up (to study diligently), rushee (a candidate for membership if fraternity or sorority), mouse (to neck or to pet) pizza face (person with facial acne) and brewski (a beer) (Coleman 2012, 50-61).

It can be concluded that English Slangs is not register. It is an alternative daily language which is used as an individual term and it is used in an informal situation. In daily life, people will speak more relax, forgetting about the grammar such as forgetting about word order but In English Slang, people will not only forget grammar, they also changed part of speech such using easy as a verb not as an adjective.

\section{English Slangs Users}

Green (2015:343) said that the young - or certainly working class- 
undoubtedly used Slang in the nineteenth century. According to Coleman (2012:18), it is only relatively recently, afterworld II, that young people have been considered the main user's creators of slang. Furthermore, he said the infantry were depicted as fluent slang users during World War II (at the bottom); with RAF officer using the most during World War II (back up top again). These were all young men, but they were not considered representative young people or young men as a whole.

In other words, English slangs are mostly used by young people. They are also as the form of creativity, witty and reinvention. They will change in spelling of Standard English such as want become wanna. There is always new coinage of English slangs because the existence of English slangs is short.

\section{Types of English Slangs}

English Slangs was created by Standard English. Coleman (2012:29) said that a great many slangs word are derived from Standard English and it is often possible to trace their development through closely related sense. According to Coleman there are seven types of English Slangs, they are;

\section{a. English Slangs Created by Changes Meaning}

Eble (1996:53) said that because of Slangs are identical in form to word and expression in general vocabulary, the meaning of a Slang term can be described as series of increasing divergences from general usage.

English Slang that is derived from a Standard English could be amelioration, pejoration, and generalization. Amelioration is English Slang derived from standard English by changing the negative meaning into to positive such as boob, it is mean fool in standard English but become girl in English Slangs, Pejoration is opposite of amelioration such as pussy means $a$ cat in standard English but it become coward in English Slang, and generation guy means man but it become man and woman in English Slang.

It can be concluded that there are at least three characteristics of The English Slang could be created by changes in meaning;

1. It is connotation.

a. Amelioration, changing from negative to positive and

b. Pejoration, it is opposite of amelioration.

2. Generalization, it makes the meaning of the word to be used generally.

3. The last, it is denotation, increasing number of contexts carries meaning itself.

\section{b. English Slangs Created by Changing in Function}

Eble (1996:33) said that the sources vocabularies of the English language are made more flexible by the ability of English words to shift in grammatical function without undergoing an alternative in form.

Eble (1996:34) also said that yet sometimes a shifted from does catch on, in Slang just as in the language in general. Noun shift to verb in flag "make the grade f" ( I am afraid I flagged the test); scope "look for 
members of the opposite sex" (make spent the afternoon sitting on the jock scooping); potato ( lie around doing nothing) and $\mathrm{x}$ stop or eliminate ( I just want to potato all weekend). In my bust "my fault", raise "parent", and skip "tennis shoes" verb have shifted to a noun. An adjective shifted to noun "my fault" and to verb in harsh "criticize, belittle" (I cannot stand the way that James hashing on the carol. A more complicated shift results in the adjective/adverb later becoming a verb meaning "put an end to a relationship" as in "Jennifer's boyfriend lathered her the week before the pledge formal"

It can be concluded that English Slang can be derived from standard English by changing part speech such as adjective shifted into a verb, easy (ask someone to calm down).

\section{c. English Slangs Created by Changing In Form}

According to Coleman (2012:35), Standard English words can also be combined in irreverent and humorous ways to create Slang synonyms. For example, the head has been described as the knowledge box (1785 -), the mouth as the cakehole (1943-) and a mustache as a soup strainer (1867-). Moreover, Coleman said that occasionally, combining forms will take on a special meaning in Slang words. For example, head is used to create compounds meaning "an individual who overindulge in (a substance)"

Eble (1996:31) said that as in general vocabulary of English, slang permits the compounding of words of various grammatical classes, with the exact relationship between the parts unspecified. redneck 'stereotypical rural' and big-time "to a superlative degree" show the ADJECTIVE+NOUN. Jambox and boogie box, both meaning "portable stereo tape deck", combine VERB + NOUN.

It means that English Slangs can be derived from the available Standard English by putting aside word as unity. It could be word + word such as (ass hat), word + additional of short such as (hook up), Adjective + noun such as (sweetheart), and verb + noun such as (kick-ass).

\section{d. English Slangs Created by Abbreviation}

According to Coleman (2012:37), Slang term can also arise from the type of abbreviation of Standard English term. He said also the beginning of the word can be omitted, as in $z a$ for pizza (1980) or sup for what's up? (1981) or the end of the word can be omitted. Sometimes pairs of words are abbreviated and combined in blends, such as gaydar "the ability to recognize a (fellow) homosexual" (1982 -), fugly "fucking ugly" (1984) (Coleman, 2012:38).

Eble (1996:35) also argued that two kinds of shortening reduce a word to a letter. The dominant type in college slang is initialism, which names the individual letter: BFE (bum fucking Egypt) "in the middle of nowhere, far away", KO (kick-off)...NDB (no big deal) NC (no class) NCAA (no class at all). Acronym in which the letter is pronounced as a word: for example nail (nice ass in Levi's), tan (tough as nails), 
the ugly (the under the graduate library). It means that there are some characteristics of English Slangs could be created by abbreviation; The First, Slangs omitted at beginning of the word such as rents for parents, file from profile (show off, dress up) and welk from welcome. Second, they can be omitted at the end of the word such as bro and broth from brother, cash from casual and coke from cocaine. Third, they are the abbreviation and combining word such as blog for a web blog. And the last, they are an initialism and an acronym. They stand for words but both they are different. Inialislism is pronounced letter by a letter such as PMS, (premenstrual syndrome or putting up with men's shit), GWS (get well soon) and OTL (out to lunch) and the acronym is pronounced as a word such as ILU(I love you), and IMU (I miss you)

\section{e. English Slangs Created by Changing in Spelling.}

English Slangs could be derived from a wide range of Standard English by manipulating sound in other hands by respelling a word. Coleman (2012:39) said that a relatively recent source of slang is typography variation: the respelling of words to indicate that they are being used in a specific sense...in its simple form, this typographical variation involves the insertion of the symbol represent of sound example $m 8$ for "mate" and CU for "see you"... Rap artists often use respelling such as "a" for "-er" example nigga, Gansta and " $-z$ " for " $s$ " example boyz, guyz to express their rejection of conventional value.

It can be concluded that English Slangs can be derived from Standard English by changing in spelling. At least, there are two forms, first by inserting the symbol which represents a sound such as 4 represent for and second, respelling word.

\section{f. English Slangs Loans}

Some Standard English words are derived from another language. It is also the way to create English Slangs according to Coleman (2012:44) of course, slang words are not always generated from existing English words. Some are borrowed from another language, including "medico doctor; a medical student" from Italian or Spanish. Soldiers have more opportunities to travel than many other people. Some of the slang words picked up by British soldier through the years include wallah man from a Hindi suffix meaning "pertaining or connecting with" but used in English compound as if it were a noun meaning "man" (1785 - )

\section{g. English Slangs from Sound}

In this case, English Slangs could be created by imitating a sound, according to Coleman (2012:45) most Slang comes from adapting the use or from of existing words, but Slang also creates entirely new words. Imitative (also called echoic and onomatopoeic) words often informal and sometimes humorous even they are widely used as direct representations of sounds like 
clink (c. 1386), boom (c.1440 -), and quack (c.1577-).

\section{Reasons for Using English Slangs}

Coleman (2012:3) said that the reasons for using English slangs. First, to impress one another or any girl that might happen to be passing them. Second, to exclude passers-by from their conversation, including the policeman and eavesdropping journalist. Another reason why they use it is to express their sense of belonging to a particular group. Moreover, Eble (1996:11) also said that Slang is an ever-changing set of colloquial word or phrases that speaker uses to establish or reinforce social identity or cohesiveness within a group or with a trend or fashion in society at large.

It can be concluded that at least, there are three reasons why people use English Slangs. First, they feel proud to use English Slangs, second, using of English Slang is because of as identity of a group and the last, people use English Slangs for excluding passers-by from their conversation.

\section{RESEARCH METHOD}

The researchers used a qualitative research design to analyze English slangs found in The Ant Man movie. The first step in collecting the data was by finding the Ant Man's script from the internet and followed by watching the movie. Next, the researchers selected and coded the English slangs used in the dialog of the movie. After that, the researchers found the meaning of slangs words based on the dictionary and context of the dialog. The last, the data were classified and tabulated based on the types of slangs proposed by Coleman theory.

\section{FINDINGS AND DISCUSSION}

\section{A. FINDINGS}

To identify English Slangs, the researchers observed all data found in The Ant Man movie. Then the researcher analyzed and described all of the data especially data related to English Slangs found in The Ant Man movie. The researchers identified English Slangs used in the Ant Man Movie based on Coleman's theory. According to Coleman (2012: 23) to work out whether these examples were slang or not, the reader needs to know who speaking, who they were speaking to, where they were, what they were doing when they were speaking, and what they meant.

After reading the script of movie and coding the English slangs found in the movie researchers classified English Slangs based on Coleman's theory; English slangs created by changing in meaning, English slangs created by changing in function, English slang created by changing in form/compounding, English slangs created by abbreviation/ shortening, English slangs created by changing in spelling, English slangs created by borrowing, and English slangs created by playing with sound.

Here is the description of types of English slangs found in the Ant Man movie. 


\section{a. English Slang created by changes in meaning}

English Slangs could be created by changes in meaning. The English Slang derived from changing in meaning are; first, connotation such as cool, pussy, boob, ass, dog, hell, damn, shit, and bitch. Second, it is a generalization, such guys. Third, it is denotation such as peanuts and baby.

There are three kinds of English Slangs could be created by changing in meaning. The first, it is connotation.

(1) Cool means showing no friendliness toward person or enthusiasm for an idea or project but it becomes "excellent" in The English Slang. (2) Damn means "curse" but it become “(a) excellent" (3) Pussy means a cat but it becomes a coward in The English Slang. (4) Boob means fool but it becomes a girl in English Slang. (5) Ass means a buttock but it becomes fool (6) Dog means a carnivorous mammal that typically has a long snout, an acute sense of smell, and barking, howling, whining voice but it becomes a man in English Slang. (7) Hell means a place regarded in various as a spiritual realm of evil and suffering but it becomes a feeling annoyance in The English Slang. It is a generalization, (8) Shit means feces but it becomes "non-sense" in The English Slang. (9) Bitch means female dog but it becomes "complaining" at The English Slang. The second, (10) Guy means a man but in the English Slang can be used for man and woman and (11) brother means a boy has a relationship to other sons of his parents but it becomes "friend" in English Slang. And third, it is denotation (12) Peanut means the plant of the pea family planted underground and but it becomes "an endearment call". (13) Baby, a baby means "young child" but become endearment call (14) Sweetie means the pleasant taste of sugar but it becomes "endearment call". (see table 1.)

Table.1 English Slangs created by changes in meaning

\begin{tabular}{|c|c|c|c|}
\hline \multicolumn{2}{|c|}{$\begin{array}{l}\text { English Slangs created by changes } \\
\text { in meaning }\end{array}$} & English slangs & Meaning \\
\hline \multirow[t]{2}{*}{ Connotation } & Amelioration & $\begin{array}{l}\text { 1. } \text { Damn } \\
\text { 2. Dude } \\
\text { 3. Boob } \\
\text { 4. Ass } \\
\text { 5. Dog } \\
\text { 6. hell } \\
\text { 7. cool } \\
\text { 8. bitch } \\
\text { 9. } \text { shit }\end{array}$ & $\begin{array}{l}\text { 1. Exclamation of annoyance } \\
\text { 2. Stupid: lacking intelligence } \\
\text { 3. Girl: a young or relatively young woman } \\
\text { 4. Fool; stupid } \\
\text { 5. A man: an adult human male } \\
\text { 6. Exclamation of annoyance } \\
\text { 7. Excellent: Extremely good; outstanding } \\
\text { 8. Complain: expressing dissatisfaction } \\
\text { annoyance about a state of affairs or an event } \\
\text { 9. Rubbish; Nonsense }\end{array}$ \\
\hline & Pejoration & 1. pussy & $\begin{array}{l}\text { 1. Coward: a person who lacks the } \\
\text { courage to do or endure } \\
\text { dangerous or unpleasant things }\end{array}$ \\
\hline \multicolumn{2}{|c|}{ Denotation } & $\begin{array}{l}\text { 1. peanuts } \\
\text { 2. baby }\end{array}$ & $\begin{array}{l}\text { 1. Endearment call for someone } \\
\text { 2. Endearment call for someone }\end{array}$ \\
\hline
\end{tabular}




\begin{tabular}{|c|c|c|}
\hline Generalization & 1. Guy & 1. Used to man and woman \\
\hline
\end{tabular}

\section{b. English Slang created by changes in function}

After analyzing the data, researchers only found two English Slangs created by changes in function; Easy and grown-up. (see table 2.)

In scene 1

Mitchell Carso: If only you would protect Janet (Hang's wife) with such ferocity, Dr. Pym

Scientist: Easy Hang! (Scene.1, ES.1)

Based on the context, the expression Easy fulfills criteria as an English slang. Hang is one of the characters in the Ant Man Movie was not happy because Mitchell Carson jeered that Scott could not keep safe his wife and hit Mitchell Carson. And Peggy Carter tried to separate them and said "easy, Hang," The researchers think that easy means "keep calm". It is an adjective, not a verb so it must be The English Slang.

While in scene 25

Cassie : Is daddy a bad man? I heard some grown-up (S.25, ES.91) say he is bad.

Maggie : No, Daddy just gets confused sometimes. Do you know?

In this dialog, the expression grown-up is in the past participle form of the verb "grow up". It means mature or adult. Cassie got to hear someone talked about Cassie's father at the birthday party and Cassie got to feel annoyance and ask Cassie's mom, Maggie. The researcher thought that because of quarreling between Paxton and Scott and it makes adult talked about Scott.

Table. 2 English Slangs created by changes in functions

\begin{tabular}{|l|l|l|}
\hline \multicolumn{1}{|c|}{ Word } & \multicolumn{1}{|c|}{ Dialog } & \multicolumn{1}{c|}{ Meaning } \\
\hline Easy (adjective) & $\begin{array}{l}\text { Easy Hang! } \\
\text { Easy (verb) }\end{array}$ & $\begin{array}{l}\text { Keep calm: not showing or } \\
\text { Feeling nervous, anger or other } \\
\text { emotions. }\end{array}$ \\
\hline Grown-up (verb) & $\begin{array}{l}\text { I heard some grown-up } \\
\text { say he is bad. } \\
\text { Grown-up (verb) }\end{array}$ & $\begin{array}{l}\text { Adult: a person who fully grown } \\
\text { or developed }\end{array}$ \\
\hline
\end{tabular}

\section{c. English Slang created by changes in form}

English Slang word can be derived from the available Standard English word and it is created by putting aside with other words as unity.
The characteristics of compounding are verb + noun,

verb + addition of short, Noun + Noun, and adjective + noun. Ten English Slangs created by changing form were found in the Ant Man Movie (see table $3)$. 
Table.3 English Slangs created by changes in form

\begin{tabular}{|c|c|c|}
\hline Word & Dialog & Meaning \\
\hline verb + noun & kickass & $\begin{array}{l}\text { Hit: carry one's hand or tool or } \\
\text { weapon into contact with } \\
\text { (someone or something) }\end{array}$ \\
\hline $\begin{array}{l}\text { verb }+ \text { addition of } \\
\text { short }\end{array}$ & $\begin{array}{ll}\text { 1. } & \text { hook-up } \\
\text { 2. } & \text { kick it with } \\
\text { 3. } & \text { cocky }(\operatorname{cock}+\mathrm{y}) \\
\text { 4. } & \text { sweetie }(\text { Sweet }+\mathrm{ie})\end{array}$ & $\begin{array}{l}\text { 1. A favor: help someone to do } \\
\text { something } \\
\text { 2. Keep in touch } \\
\text { 3. Conceited: excessively proud of } \\
\text { oneself } \\
\text { 4. Endearment call for someone }\end{array}$ \\
\hline noun + noun & 1. ass hat & Impertinent: rude \\
\hline adjective + noun & $\begin{array}{l}\text { 1. } \text { sweetheart } \\
\text { 2. Hotdog } \\
\text { 3. Hotshot } \\
\text { 4. big-shot } \\
\text { 5. good boy }\end{array}$ & $\begin{array}{l}\text { 1. Endearment call for someone } \\
\text { 2. Exclamation of delight or exultation } \\
\text { 3. Skilled person } \\
\text { 4. High ranking or important person } \\
\text { 5. Compliment: praise or admiration }\end{array}$ \\
\hline
\end{tabular}

d. English Slang created by the abbreviation

The abbreviation is one way of creating English Slangs by omitting a part of the word. It can be at the beginning or the end of the word. According to Coleman (2012:37), Slang term cab also arise from the type of abbreviation of Standard English term. He said also the beginning of the word can be omitted, as in za for pizza (1980) or sup for what's up? (1981) or the end of the word can be omitted. In this research, five English slangs created by abbreviation were found. (see table 4).

Table.4 English Slang created by the abbreviation

\begin{tabular}{|l|c|l|}
\hline \multicolumn{1}{|c|}{ Abbreviation } & The English Slangs & \multicolumn{1}{c|}{ Meaning } \\
\hline $\begin{array}{l}\text { omitting at the beginning of } \\
\text { words }\end{array}$ & 1. 'cause & Because: for the reason; since \\
\hline omitting at the end of words & $\begin{array}{l}\text { 1. bro; } \\
\text { 2. Chillin' }\end{array}$ & $\begin{array}{l}\text { 1. Friend: a person whom } \\
\text { one knows and with whom } \\
\text { one has a bond of mutual } \\
\text { affection, typically exclusive } \\
\text { of sexual or family relations. } \\
\text { 2. Chill: make (someone) } \\
\text { cold } \\
\text { 3. What: asking for }\end{array}$ \\
\hline
\end{tabular}




\begin{tabular}{|l|l|l|}
\hline & & $\begin{array}{l}\text { information } \\
\text { specifying something }\end{array}$ \\
\hline abbreviation and combining & 1. & $\begin{array}{l}\text { 1. Come on: persuading } \\
\text { someone to do something }\end{array}$ \\
\hline
\end{tabular}

From the table 4. English slangs created by abbreviation by omitting at the beginning of a word is 'cause. It is a short form of because. Sometimes in conversation, because can be also shortened become coz means for the reason. Bro, Chillin', and wha? Are the form of English Slangs by omitting at the end of words. While $C^{\prime} m o n$ is an abbreviation of come on. C'mon means to persuade someone to do something. Maggie persuaded Scott to leave
Paxton's house because Maggie has not believed that Scott has changed.

\section{e. English Slangs created by changes in spelling}

English Slang could be created by changes in spelling. Researchers found six English Slangs created by changing in spelling found in the Ant Man Movie. (See table 4). It is also happening in daily conversation.

Table. 5. English Slangs created by changes in spelling

\begin{tabular}{|c|c|c|}
\hline Changes in spelling & The English Slangs & Meaning \\
\hline $\begin{array}{l}\text { The manipulation of } \\
\text { sound for fun with } \\
\text { flippant }\end{array}$ & $\begin{array}{l}\text { 1. wanna, it could be derived } \\
\text { from } \\
\text { want, } \\
\text { 2. gonna, it could be derived } \\
\text { from } \\
\text { be going to, } \\
\text { 3. gotta, it could be derived from } \\
\text { go to, } \\
\text { 4. yeah, it could be derived } \\
\text { from } \\
\text { yes, } \\
\text { 5. kinda it could be derived from } \\
\text { kind of } \\
\text { Nah, it could be derived from } \\
\text { no }\end{array}$ & $\begin{array}{l}\text { 1. Want: a desire to do } \\
\quad \text { (something) } \\
\text { 2. Be going to; will } \\
\text { 3. got to; must } \\
\text { 4. Yes: agreement } \\
\text { 5. Kind of: a group of } \\
\text { people or things having } \\
\text { similar } \\
\text { 6. Not any }\end{array}$ \\
\hline
\end{tabular}




\section{f. English Slang loans}

The phenomenon of borrowing a word from another language is caused by the contact of people from different language society. Some Standard English words are derived from another language. It is also the way to create English slang according to Coleman (2012:44) of course, Slang words are not always generated from existing English words. Some are borrowed from another language, including "medico doctor; a medical student" from Italian or Spanish.

A type of The English Slang with borrowing from other languages are dude and pronto. First, (1) Dude, it could be derived from German dialect. Second, (2) Pronto, it could be derived from Spanish. And the last buddy (3) and what's up? (4), it could be derived from are from African-American (see table 6).

Table. 6. English Slangs loanskki

\begin{tabular}{|c|c|c|}
\hline English Slangs loans & The English Slangs & Meaning \\
\hline $\begin{array}{l}\text { Borrowing from other } \\
\text { languages }\end{array}$ & $\begin{array}{l}\text { 1. dude; borrowed from Germany } \\
\text { 2. pronto; borrowed from Spanish } \\
\text { 3. buddy; borrowed from African- } \\
\text { American, } \\
\text { 4. what's up, borrowed from African- } \\
\text { American, }\end{array}$ & \begin{tabular}{|l} 
1. \\
stupid: lacking \\
intelligence \\
2. Quickly: \\
moving fast \\
or doing \\
nething in a short \\
time \\
3. A friend \\
4. Greeting \\
expression; \\
How are you?
\end{tabular} \\
\hline
\end{tabular}

\section{g. English Slangs play with sound}

English Slang could be created by imitating the sound. English Slangs are (1) mommy and (2) daddy according to Oxford Dictionary of Slang
(1998:51) daddy; perhaps from imitative child's da-da and Mummy; imitative child's pronunciation. In this research, two English slangs play with sound; mommy and daddy. (see table 7).

Table. 7. English Slangs play with sound

\begin{tabular}{|l|l|l|}
\hline play with sound & $\begin{array}{l}\text { The English } \\
\text { Slangs }\end{array}$ & \multicolumn{1}{|c|}{ Meaning } \\
\hline Onomatopoeias & $\begin{array}{l}\text { 1. Mommy } \\
\text { 2. Daddy }\end{array}$ & $\begin{array}{l}\text { 1. Mother: woman in relation to a child or } \\
\text { children to whom she has given birth } \\
\text { 2. Father: a man in relation to a child or } \\
\text { children. }\end{array}$ \\
\hline
\end{tabular}




\section{B. Discussion}

Based on the present finding, it was shown that the English Slang is "highly colloquial" in the sense that is further away from Standard English. Harared (2018) states that slang uses informal words and expressions that are not considered standard in the speaker's language. By speaking in colloquial English, one indicates that they are a warm, friendly, and approachable individual who wants to connect with other human beings on a personal level.

These were found in Scene 7, Dave said that Baskin Robbins doesn't play. It should be "Baskin Robbins does not play". In colloquial, do not think too much about grammar. In scene 11, Hope said that "who?" Hope asked about the man trusted to be ant man. It should be "who is the guy?" it is far from a Standard English but in scene 5, Scott used dude to replace stupid/fool. It changed the meaning. Dude means a stylish person so The English Slang is far away from Standard English. Another example; in scene 7, Dave used fussy to replace a coward. Pussy means "a cat". The English Slangs changed its meaning. Sometimes it used an adjective as a verb such as in scene 1 , Peggy Carter used easily to replace keep calm. The researcher believed that easy is an adjective so The English Slangs is far away from Standard English and it is also confirmed that people use The English Slang for rebelling Standard English.

The finding is also shown that to identifying The English Slangs, The researcher needs to know about the context of statement/sentence. In scene 5, Scott used dude to say "stupid". Scott got angry because the customer ordered a hot meal in the Baskin Robbins, Ice cream shop but in scene 16, Emily used dude to say "a man". Emily talked about Hang whom Emily worked as a housekeeper. Other examples, in scene 7, Luis used damn to say "feel annoyance" because finally, Baskin Robbins know that Scott is crook and Scott got fired but in scene 17, Dave used Damn to say "compliment" because Scott can pass the wall just with once chance. In scene 16 , boobs mean "fool" but by looking at its context, whom Luis talked about, Emily so in English Slang, it means a girl.

There were seven types of English Slangs. First, it is changing in meaning such as pussy means "a cat". It became a coward, bitch means "female dog". It became "exclamation of complaint" and Damn means "curse". It becomes "excellent". Second, it is changing in function such as easy is an adjective become a verb. Third, it is changing in a form such as Hot-dog, ass-hat and sweetheart. Forth, it is abbreviation such as bro and chillin'. Fifth, it is changing in spelling such as gonna, wanna and kinda. Sixth, it is borrowing such dude from German dialect. The last, it is playing with sounds such as daddy and mommy. Based on the finding could be concluded that from seven etymologies, the numbers of English Slangs created by changes in meaning were highest from other types are the English Slangs created by changes in 
meaning are fourteen of The English Slangs found in the Ant Man Movie

Based on the previous research, use of English Slang was caused of excluding the other from the conversation. They use slang words as a secret code and solidarity marker inside the groups or between the group and other groups (Coleman, 2012). In was also found in the Ant Man, The English Slangs also found such as dude. It happened at work when the Scoot felt annoyance about the customer who bought a hot meal at ice cream Shop. Scott explained again that is an ice cream shop but the customers asked again. English Slangs for excluding others from the conversation is not significant because spreading the English Slang by electronic media or printed media so it is possible for everybody knows it.

Moreover, from this research, it can be known that some English Slangs are taboo, vulgar, derogatory, nor offensive in meaning, sound or image. In the ant man movie, it is also found such as bitch and hot dog. It is connotation, amelioration, a negative meaning become positive such as bitch; complaining and hot dog; an exclamation of delight. Moreover, a man frequently tends to use taboo words than a woman. It seems slangs also related to gender issue. This was in line with the research finding that males and females had differences in conversational style. „Male speakers often use tabooed words and slang in their daily speeches. To be exact, tabooed words and slang can be found more frequently in men"s language than in women"s, though they are of the same educational level" (Ning, Dai \& Zhang 2010: 127).

The English Slangs which is derived from other language was hard to be conducted. The researcher got to know the indicators from The English Slangs loans. To overcome to trace the etymology, the researcher consulted with the books and the Oxford English Dictionary.

\section{G. Conclusion}

The researchers conducted the researcher about the analysis of English Slangs found in The Ant Man Movie. The researcher used a transcript of The Ant Man Movie to analyze The English Slangs. Based on the question of formulation of the research, the researcher concluded that there are forty-four The English Slangs such as easy Hang. It means to keep calm. It is the English Slang depending on context and criteria of the English Slang. The researchers also classified English slangs into seven types first, The English Slang changes in meaning. Second, The English Slangs change in function. Third, The English Slangs change in form. Forth, it is the abbreviation of English Slang. Fifth, English Slangs changes in spelling. Sixth, it is the English Slangs loans, the last, The English Slangs plays sound.

\section{REFERENCES}

\author{
Aitchison, J. 2015. What's up? Slang \\ and swearing among children \\ Vol. 19: 18-21.
}


Arifin, Z. 2011. Penelitian Pendidikan Metode dan Paradigma Baru. Bandung: PT. Remaja Rosdakarya.

Ayto, J. 1998. Oxford Dictionary of Slang. New York, United State of America: Oxford University Press.

Coleman, J. 2012. The life of Slang. New York, United State of America: Oxford University Press.

Eble, C. 1996. Slang and Sociability. North Caroline, United State of America: The University of North Caroline Press.

Eriksen, Mads H. 2010. A Study of Micro Strategies in Subtitling with a View to Researching the Transfer of Slang from Source to Target Text with I loved you, Man as empirical example, including a study of function of Slang. Canada; Aarhus University

Green, J. 2015. The Vulgar tongue and green's history of Slang. New York, United State of America: Oxford University Press.

Harared, Nico. 2018. Slang Created And Used In 1cak.Com Site: A Sociolinguistics Study. Humaniora Vol. 9 No. 2 July 2018.

Ning, Haiiang \& Dai, Xue, 2010. On Gender Difference in English
Language and Its Causes. Asian Social Science, 2010, Vol. 6. No. 2.

Novariga, Hanna.2013. An analysis of Slang word in Discussing forum at English Zone Community. Pekanbaru, Riau: Islamic Riau University.

Pedersen, T. 2007. The use of Slang in British English; A study of the Slang used in football Factory and little Britain. England: The University of Kalmar.

Sugiyono. 2010. Penelitian Pendidikan; Pendekatan kuantitatif, kualitatif, dan R\&D. Bandung: Alvabeta, CV.

Sunny, Ni Putu Wintia. 2015. Three Approaches of word sentence meaning in translation of English Slang word into Indonesian in the novel "the adventure of Oliver twist Vol. 7, No. 1.

Yuliana, Tiarma Ika. 2015. Analysis of American Slang movie Vol. 1, No. 1. 